\title{
ART ADDRESSING THE ANTHROPOCENE
}

\section{A B S T R A C T}

The current diagnosis that the era we are living in ought to be conceived as anthropocene has two implications: a. Human activity is changing the superficial as well as the deep structure of our planet to a formerly unknown degree. $b$. The foreseeable catastrophic consequences of our impact on life on this planet command a fundamental change of our technological-consumerist attitude. - How can the arts address this situation?

One (relatively superficial) option is ecological art. But, despite all its good intentions, it often just contributes to the widespread sedation procedures that prevent us from taking the neces-sary measures. A different option consists in exploring a possible future of the planet that no longer counts or relies on humans (which, due to their activities, might anyway disappear in a few decades). Nature might then take its own way again. How can art picture a no longer hu-man-based future state of our planet? This is what the paper tries to elucidate along some ex-amples from the arts. In the end, however, depicting a possible vanishment of humans also stimulates efforts to avoid this.

\section{Wolfgang Welsch \\ Friedrich Schiller University Jena \\ wolfgang.welsch@uni-jena.de}

KEY WORDS

ANTHROPOCENE

CONTEMPORARY ART

NOVEL LIFE FORMS

NATURE INVADING MUSEUMS

EARTH WITHOUT HUMANS

ECOLOGICAL ART

FUTURE

TSUNAMI BOULDERS 


\section{THE MODERN WAY OF THINKING}

\section{AND THE PROBLEM OF THE ANTHROPOCENE}

'If we banish man or the thinking \& contemplating being from above the surface of the earth, then this moving and sublime spectacle of nature is nothing but a sad and silent scene. The universe is dumb; silence and night overtake it. Everything changes into a vast solitude where unobserved phenomena occur in a manner dark and mute. It is the presence of man that gives interest to the existence of beings [...] Man is the sole point from which to begin, and to which all must be brought back.'

This is an exemplary formulation of the modern, anthropocentric way of thinking. It is an excerpt from Denis Diderot's article about the Encyclopedia published in 1755 .

In 1769, a very different author writes: 'Who knows the races of animals that have preceded us? Who knows what races of animals will follow us?'2 'Every animal is more or less human, every mineral is more or less plant, every plant is more or less animal. There is no sharp demarcation in nature ...' 'Everything changes, everything passes $[\ldots] .{ }^{4}$

This other author is Diderot again - but a Diderot who, in the meantime, has adopted the perspective of evolution and thus has become a strong critic of the modern way of thinking which he had proclaimed 14 years earlier. The last quotation is to be found in his essay "D'Alembert's Dream". Now man no longer is the leading figure, according to whose unique concept everything is to be understood, instead he is only one of many phenomena in the series of evolution - and neither its last nor its highest phenomenon. Now it would be foolish to want to understand the world from a human perspective. The new measure is the "general flow" of evolution. ${ }^{5}$ And this one no longer gives any honouring to man. ${ }^{6}$

These two statements from the beginning of modernity still characterise the problem of the Anthropocene in which we currently exist: ${ }^{7}$ On the one hand, there is the modern dogma of human sovereignty. But it has led us - especially through its technological effects - to the brink of the collapse of our living conditions. On the other hand there is the thought of evolution. From its point of view, the end of human civilisation could even be understood as a natural process. As in the course of evolution 99 percent of the species ever originated have died out, why should it be any different for our species? We are dependent on nature, but nature is not dependent on us. Nature will continue to exist even without us humans and will produce new species in an undisturbed manner. 


\section{POSITIONS OF ART}

How do the arts address this critical situation? There are three options.

The first and quite current one is ecological art. It makes us aware of ecological interdependencies and demonstrates possible ways of healing. There is no doubt that ecological art has great merits. But over the last few years two concerns have come to my mind. One is external: the ecological interventions have become part of a sedation industry that prevents us from taking the necessary measures. The artworks urge such measures. But in the reception they often serve as substitutes for measures that do not take place. The other concern is internal. Often (certainly not always) ecological art looks like a documentary report. It illustrates a good intention and a ready-made opinion. To be sure, all this is aesthetically arranged - but does that already make it art? "Well meant", Gottfried Benn once stated, is the opposite of art. ${ }^{8}$ And in the field of ecological works I find just too much good intention and definiteness, whereas art always requires uncertainty, ambiguity and irritation. ${ }^{9}$

The second option is not environment-centered but human-centered. It does, however, imagine a shift of the human to the post-human. This way it bypasses the question whether the earth will continue to be a place for humans or, through human activities, become an inhuman terrain. It rather imagines a transformation of the human which would make us independent of any terrestrial conditions. Artificial intelligence (AI) and virtualisation technologies are supposed to do the job. ${ }^{10}$ So the technologically caused problems of the Anthropocene are to be countered by new technologies. This is obviously at odds per se, and in addition there are serious doubts whether these techno fantasies will ever be anything other than reveries.

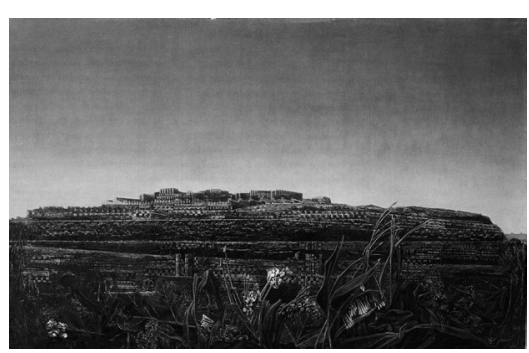

Fig. 1a. Max Ernst, Die ganze Stadt, 1936/37, oil on canvas, $97 \times 145 \mathrm{~cm}$, private collection

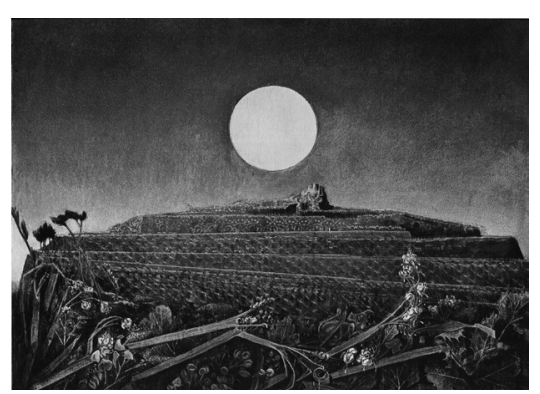

Fig. 1b. Max Ernst, Die ganze Stadt, 1935/36, oil on canvas, $60 \times 81 \mathrm{~cm}$, Kunsthaus Zürich 
Therefore I will deal with a third option only. Instead of appeasing us or bypassing the hard question of an end of the Anthropocene, this option devotes itself to exploring a possible future of the planet that no longer counts or relies on humans but takes its own way - as nature always did. So that raises the question: How do contemporary artists picture a no longer human-based (or human-contaminated) future state of our planet?

\section{EARLY VISIONS OF AN ENDING OF THE ANTHROPOCENE}

When one addresses this perspective, one should turn to certain artistic endeavors of the twentieth century before looking at contemporary art.

Max Ernst (1891-1976):

decaying cities, airplane traps, novel mixed creatures

Some of Max Ernst's paintings, for example, can be seen today as suggesting that man will, due to the consequences of his technology, disappear from the Earth and that non-human nature will recapture the areas of civilisation and, in the future, develop undisturbed by humans. (Fig. 1a)

Certainly, Ernst did not know the term "Anthropocene", nor did he have in mind the effects of climate change that make us shudder today. Nevertheless, artists are sometimes visionaries. They make something tangible that they themselves only suspect, but cannot yet identify.

In this sense, some of his paintings seem to point in the direction of an end of the Anthropocene. (Fig. 1b)

First, there are huge deserted cities. One sees only solidified and decaying architecture, but no people any more. Instead, the vegetation begins to overgrow the cities, to retrieve their space. (Fig. 1c, 1d)

Second, there are paintings showing airplane traps. Gluttonous vegetation devours airplanes, the proud symbols of technological civilisation. ${ }^{11}$ (Fig. 1e, 1f)

Third, there are paintings that show new creatures - semi-anthropomorphic hybrids - as they may populate and dominate the Earth after the end of human civilisation. (Fig. 1g) 


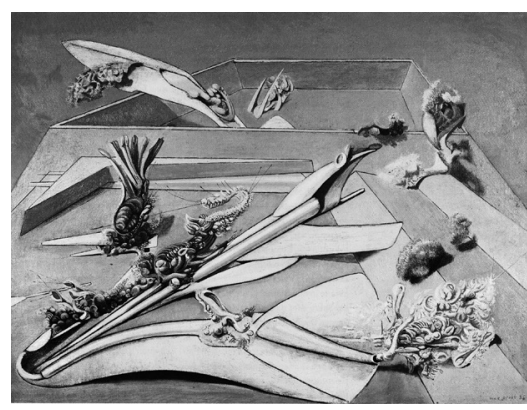

Fig. 1c. Max Ernst, Jardin gobe-avions, 1935, oil on canvas, $54 \times 74 \mathrm{~cm}$, Paris, Centre Georges Pompidou

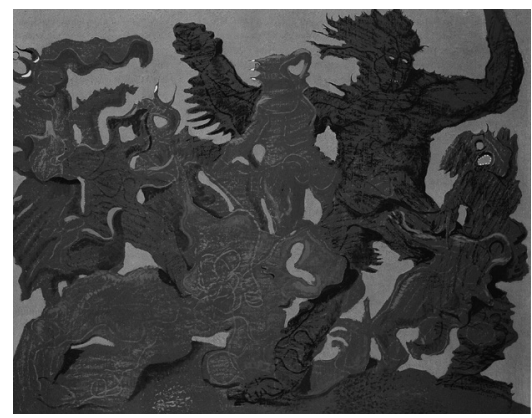

Fig. 1e. Max Ernst, Die Horde, 1927,

oil on canvas, $115 \times 146 \mathrm{~cm}$, Amsterdam, Stedelijk Museum

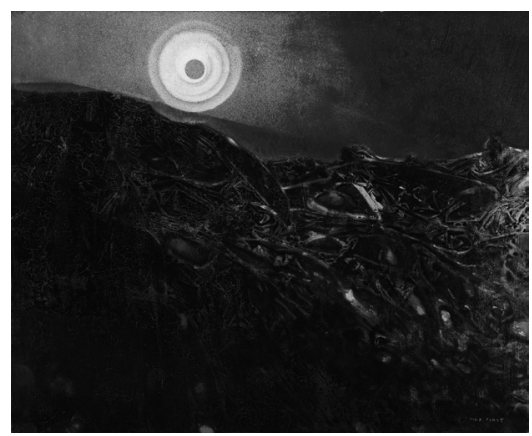

Fig. 1g. Max Ernst, The Twentieth Century, 1955, oil on canvas, $55 \times 61 \mathrm{~cm}$, Max Ernst Museum des LVR, Brühl

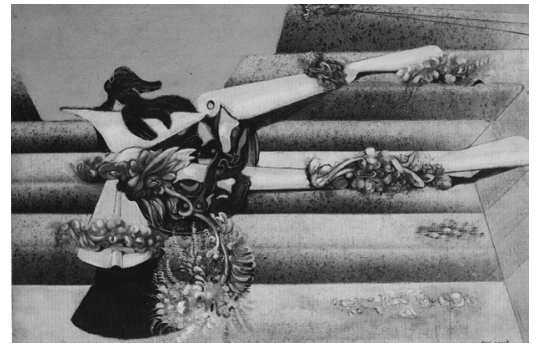

Fig. 1d. Max Ernst, Jardin gobe-avions, 1935, oil on canvas, $64 \times 61,5 \mathrm{~cm}$, Collection Mugrabi

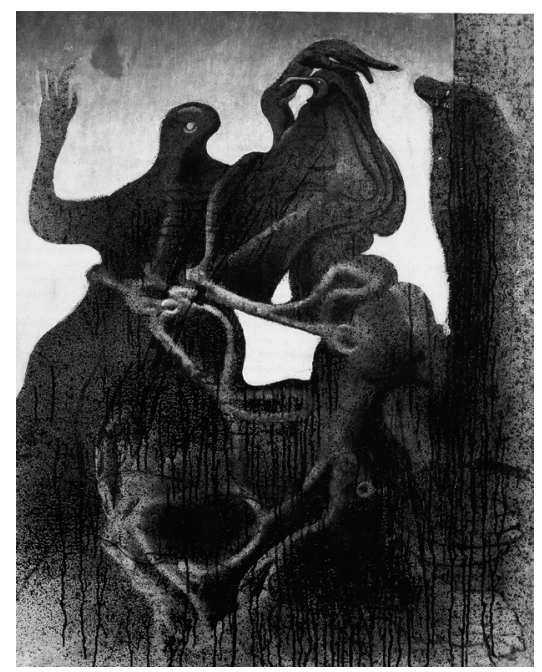

Fig. If. Max Ernst, Zoomorphes Paar in der Schwangerschaft, 1933,

oil on canvas, $91,5 \times 73 \mathrm{~cm}$, Peggy

Guggenheim Collection, Venice 
Finally, there is a mysterious (and little known) painting from 1955 titled The Twentieth Century. The deserted Earth is - in an unusually gloomy vision covered with encrusted structures; life is frozen - even the moon above it points in the direction of lifelessness. No more life-giving sun stands above the Earth, but only a dead star - itself another witness of torpidity and death.

Once again: Nobody spoke of an "Anthropocene" at that time. These works were written in the twentieth century, not in the twenty-first century. One might think of the World War I or a premonition of the World War II; or of experiences with the Moloch metropolis and the destructive consequences of technical civilisation. Ernst probably had such things in mind when he created these works. But their potential reaches - as is often the case in art - go beyond that. Such visions of the collapse of civilisation and the future in which nature will go on without man and reclaim dominion on this planet are highly relevant today in view of the Anthropocene.

Richard 0elze (1900-1980):

end expectation, novel organisms

Let us take one more trip into the past. Some of Richard Oelze's paintings today can also relate to the Anthropocene. They seem like representations of a vaguely anticipated end for mankind or like visions of novel organisms that will subsequently populate the Earth. (Fig. 2a)

First of all, the famous painting Die Erwartung (1935-1936), where a group of people look out into a landscape that has threatening features not only for us today - we almost inevitably think of gigantic smog or another catastrophe eclipsing the Earth. (Fig. 2b, 2c)

Then there are paintings that show novel mythical or mixed creatures as they could populate the Earth after human extinction. Vegetation seems to be on the way to becoming an animal or one sees chains of strange figures or new intermediate creatures between fish and other life forms - altogether organisms as they develop on the Earth post-humanity. (Fig. 2d) 


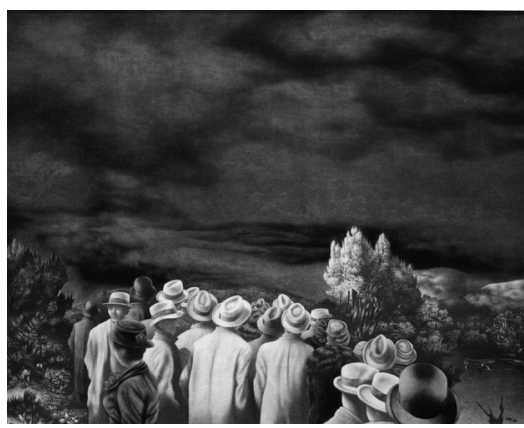

Fig. 2a. Richard Oelze, Die Erwartung, 1935-36, oil on canvas, $82 \times 101 \mathrm{~cm}$, New York, Modern Museum of Art

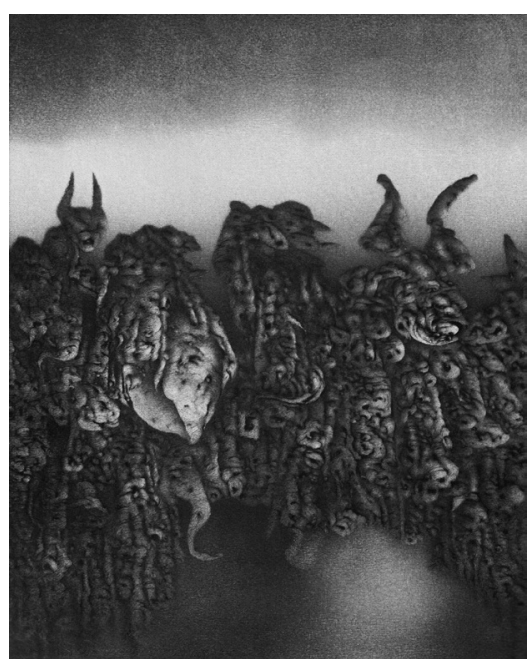

Fig. 2c. Richard Oelze, Ausserhalb, 1965 oil on canvas, 100x80 cm, Kunsthalle Bremen

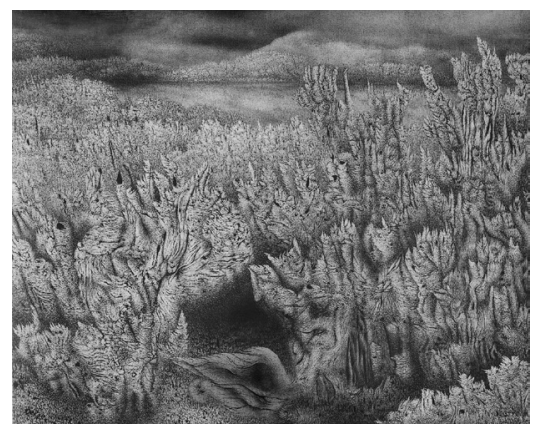

Fig. 2b. Richard Oelze, Eine Landschaft (Fernen), 1935 , oil on canvas, $33 \times 41 \mathrm{~cm}$, private collection

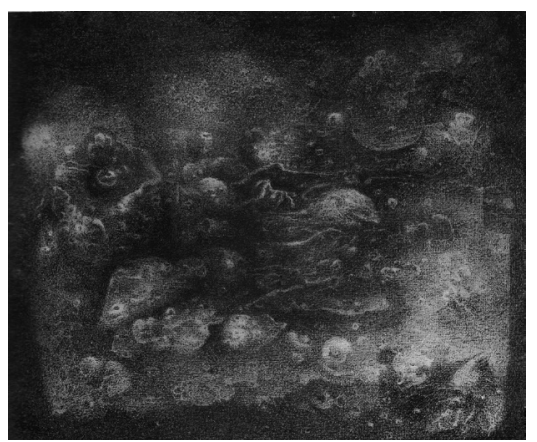

Fig. 2d. Richard Oelze, Hommage à Altdorfer (Nach einer Versuchung), 1955, Öl auf Hartfaser, 20x23,5 cm, private collection 


\section{CONTEMPORARY ARTISTIC WORKS CONSIDERING}

AN END OF THE ANTHROPOCENE

Let us now turn to contemporary thematisations of the Anthropocene and its possible end.

\section{1 dest things wi11 survive}

The first option suggests - conservatively, so to speak - that some of the oldest forms of life will continue after our species disappear. (Fig. 3a)

In their video installation Living Rocks - A Fragment of the Universe at the $58^{\text {th }}$ Venice Biennial in 2019, the Australian artists, James Darling and Lesley Forwood, presented a landscape full of thrombolites. These are rock-like living fossils that have existed for about three million years. They are called "living stones" because they look like stones. Yet they are not stones, not inorganic material, but living organisms. They are thought to have contributed to the increase in oxygen in Earth's atmosphere - and thus making possible all higher forms of life, including human life. (Fig. 3b)

Thrombolites, as this work suggests, will persist even after the end of the Anthropocene - just as they have survived many other catastrophes so far. But the human timescale is different from theirs. It is quite natural that we, who came long after them, will disappear long before them.
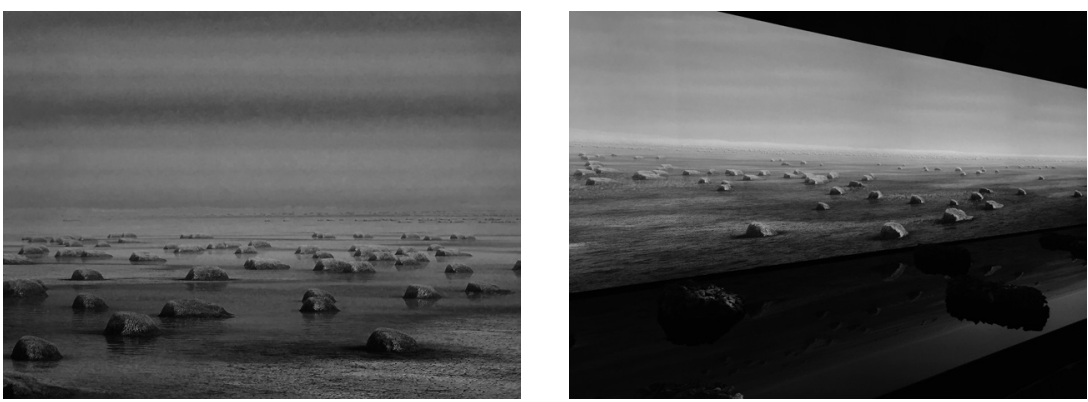

Fig. 3a, 3b. James Darling \& Lesley Forwood, Living Rocks - A Fragment of the Universe, Video installation, collateral event of the $58^{\text {th }}$ Venice art Biennale 2019 
Another example: The theater installation win $><$ win by the group Rimini Protokoll (shown in 2017-18 as part of the exhibition "After the End of the World" in Barcelona) a similar direction. It makes it clear that jellyfish are enormously robust in contrast to the fragility of human existence. Jellyfish have been floating in the world's oceans for at least 670 million years, and almost everything that damages today's ecosystem seems to do them good: overfishing of the oceans and plastic waste reduce their predators, and jellyfish thrive in warmer waters while many fish perish. (Fig. 4a, 4b)

The installation developed together with marine biologists suggests jellyfish 'will be the last to be extant when everything else decays. ${ }^{12}$

Let me remind you, in this context, that some creatures, which unlike jellyfish we value highly, are capable of withstanding the worst of civilisational devastation. In Hiroshima the first new life to stir again after the nuclear catastrophe was a mushroom - and not just any, but a matsutake, one of Asia's most valuable edible mushrooms. It grew in the city's nuclear-contaminated rubble. This mushroom is also special in as far that it cannot be cultivated, but only grows wild. ${ }^{13}$ So not only comparatively primitive creatures like jellyfish, but also some which enjoy the highest cultural esteem, are apparently able to continue to exist unaffected by the end of the human race.
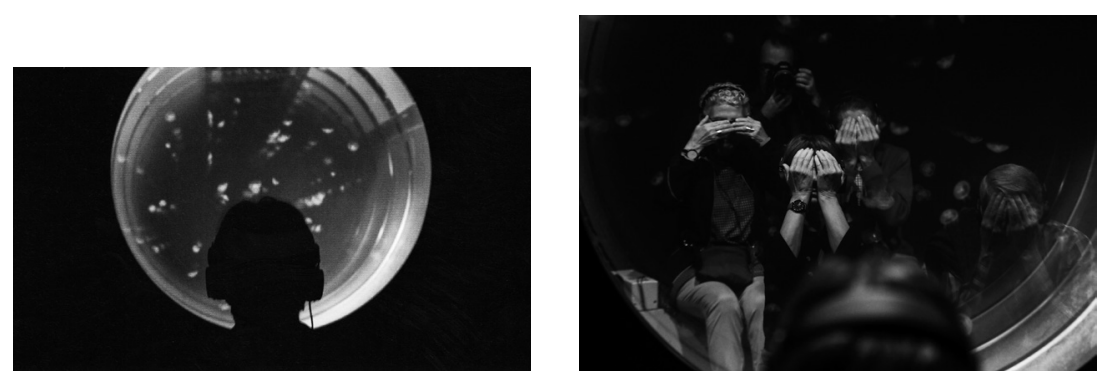

Fig. 4a, 4b. Rimini Protokoll, win $><$ win, 2017-18, exhibition "After the End of the World", 25 October 2017 - 1 May 2018, Barcelona 


\section{Novel life forms}

The second option suggests that completely new forms of life will emerge that are perfectly adapted to the new conditions through which we have put us out of business. Some artists try to imagine and visualise such future critters.

In the 2017 video entitled Precarious Inhabitants, Eva Papamargariti showed new forms of life that could be created as a result of fish or frogs ingesting plastic and thus mutate, literally incorporating the plastic components. (Fig. $5 \mathrm{a}, 5 \mathrm{~b})$

She created - as another possible prospect for the future - amorphous cell surfaces that elude any solid formation and identification.

In a similar and yet different way, Diana Danelli considered an interesting transformation of plants in her work Memoria Botanica from 2019. Plants, she thinks, will certainly survive the end of our civilisation. They account for as much as 80 percent of the Earth's biomass and are far more adaptable than humans. (Fig. 6a)

The particularly interesting point in her work is that man will no longer physically exist, but some plants will have integrated parts of the human genome into their DNA. Such integration (endosymbiosis) is nothing unusual in evolution. More than two billion years ago, some eukaryotes absorbed oxygenconsuming bacteria; this is how the mitochondria were formed, which today still are the main power generators of every animal cell. And other eukaryotes have ingested oxygen-producing bacteria (such as cyanobacteria) and thus created the basis for the later plant world. Similarly, Danelli believes plants could also absorb some human genes and use them for their purposes. (By the way, Eduardo Kac has demonstrated such an insertion of human genes into the genome of plants by means of genetic engineering. In his work Edunia [20032009] he implemented some of his own genes, which are responsible for the red colour of the blood, into the genome of a petunia, which now, as a plant-human hybrid, has red veins. $)^{14}$

Let us look back for a moment. With Ernst, the vegetation had taken over after the disappearance of man, with nothing human remaining. Human civilisation was to decay and a vegetation that has nothing in common with our civilisation was to shape the earth. It's different with Danelli. Man continues to exist in some fragments that plants have incorporated, and these human remains help the plants to new growth and variety. Man lives on as a service provider to the plant world. 

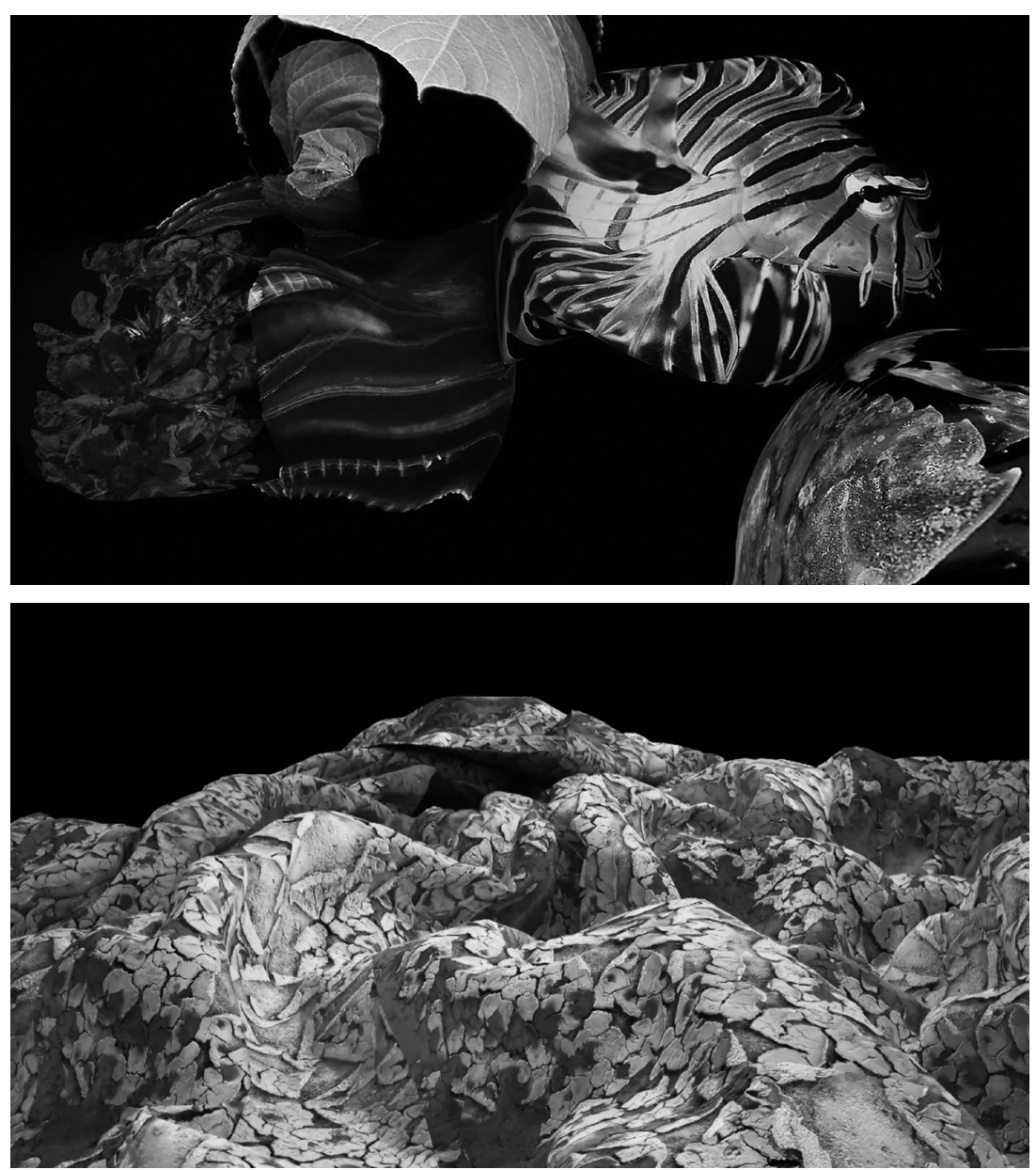

Fig. 5a, 5b. Eva Papamargariti, Precarious Inhabitants, 2017, Video, single-channel, 1920x1080, color, sound

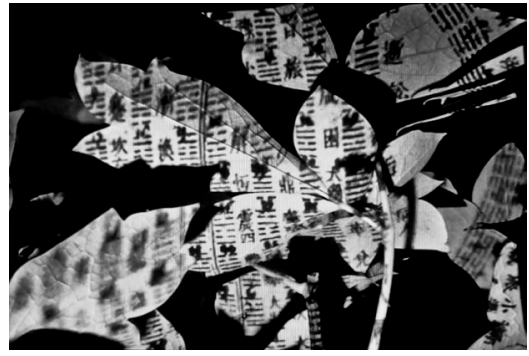

Fig. 6a. Diana Danelli, Memoria Botanica, 2019 , Digital photograph by video-projection on plants (tree-like peony leaves), color, exhibition "Greener than you Think", Bauchhund Salonlabor, Berlin, June 14-16, 2019

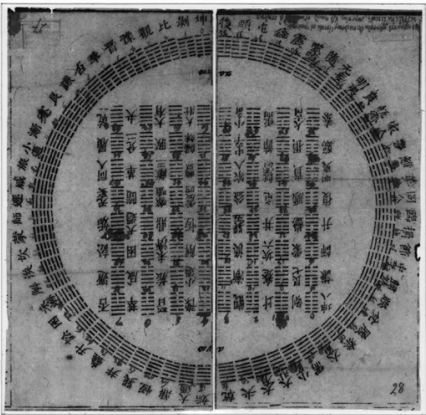

Fig. 6b. Diagram of the I Ching, author unknown, owned by Leibniz, Hannover, Niedersächsische Landesbibliothek, Leibniz Archive 
In Memoria Botanica this genetic immigration of man into the genome of plants (in this case peonies) is illustrated by the integration of a highly cultural product: a diagram of the I Ching owned by Gottfried Wilhelm von Leibniz (the great theorist of continuity from the smallest to the greatest). (Fig. 6b)

The lines of the hexagrams of the I Ching projected onto the plant leaves are much like gene sections. Maybe that's scientifically questionable. But it's beautiful and comforting. Something of human culture lives on: as a stimulation for plants or (Georg Wilhelm Friedrich Hegel would have liked it) as a spiritual impulse that now flows through the vegetable world. So in the end we humans were still of some use after all.

Anthropic narrowings in film and television

Let us now take a brief look at a completely different field - the film industry. In several blockbusters and fictional documentaries it is displayed how an end of mankind might occur and what might happen afterwards.

But these fictions imagine the disappearance of man in quite insufficient manner. It is supposed to be caused either by the invasion of aliens or by a deadly virus, or one simply assumes, without naming a cause at all, that suddenly all humans disappear from Earth. So far too little attention has been paid to the fact that people could disappear because they are destroying nature. And moreover: what, in these movies, seems to be of interest alone is what will happen to our superb civilising artifacts after the catastrophe: floods of water sweeping through New York, roads and tracks are overgrown by vegetation, animal hordes invade the cities.

All this is staged impressively or bombastically, but all of these stagings suffer from the anthropic disease. They only care about what happens to our valuable achievements, but not about how things go on with the Earth and nature beyond our human worries. In this respect, unlike the examples discussed so far, these productions are rather unimaginative.

Helmut Wimmer: The Last Day, 2018

I would like to, instead, present a series of photographs that depict the return of nature to the space of culture far more intelligently than those blockbusters do. I refer to twelve photographic tableaus that Helmut Wimmer exhibited under the title The Last Day at the Kunsthistorisches Museum in Vienna in 2018. 

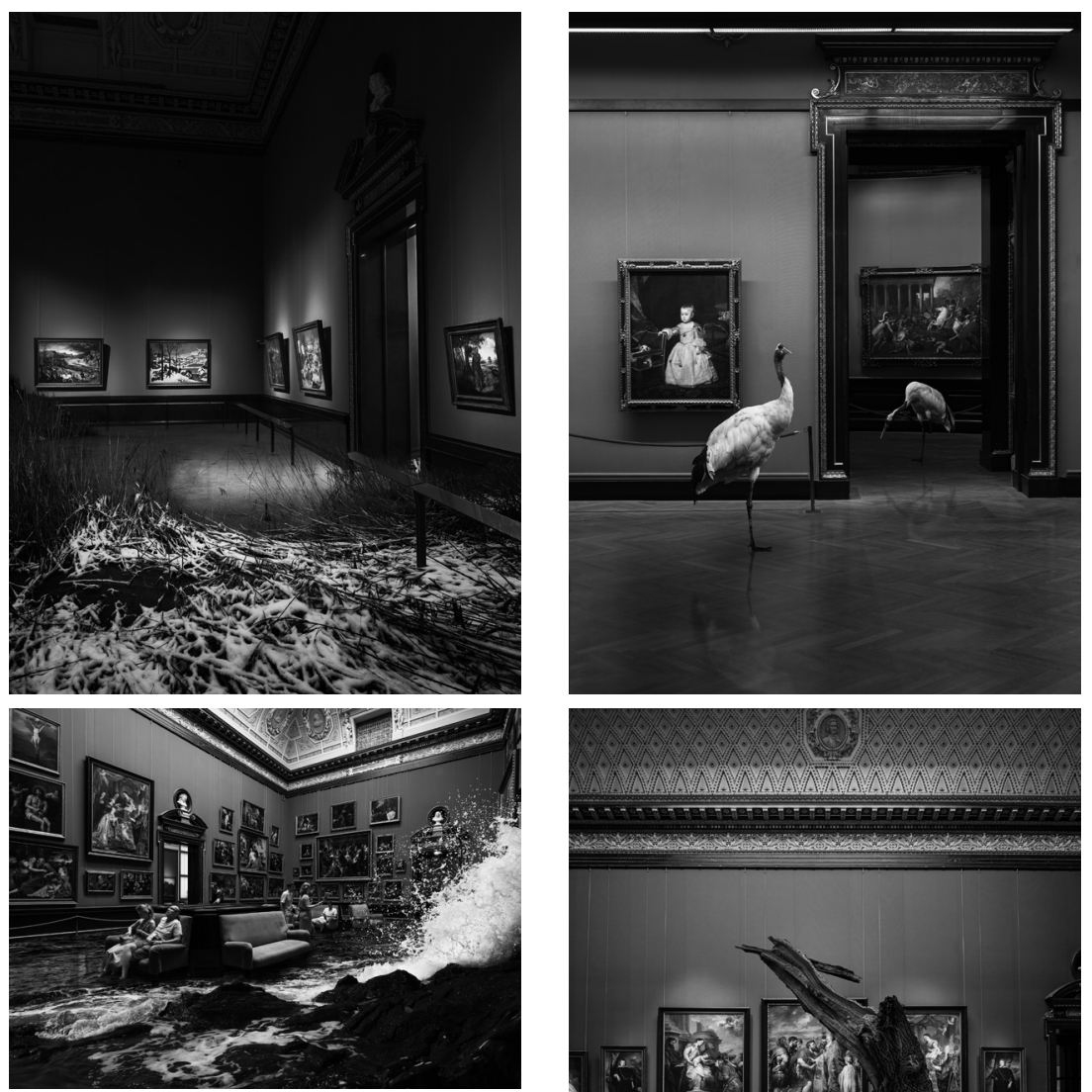

Fig. $\quad$ Helmut Wimmer, The Last Day

7a-d. 10/03/11/08, 2018, edition 4, color print/aluminium, $134 \times 100 \mathrm{~cm}$,

Kunsthistorisches Museum Wien

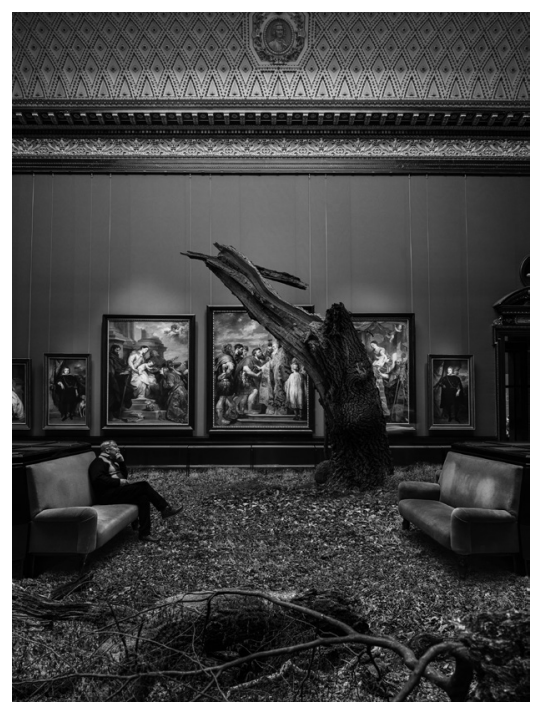


We see some familiar interiors of this famous museum, but something very unfamiliar has happened: they have been invaded by live nature. (Fig. 7a)

In the hall with Bruegel's The Hunters in the Snow brushwood and snow have spread. (Fig. 7b) Cranes strut through other halls and, in a gravitational posture, compete with the Spanish Infanta, or, in a pecking pose, with the turmoil of battle paintings. (Fig. 7c) Elsewhere, rocks and a swathe of water burst into a room - yet the museum visitors, oblivious to all this, continue to gaze at the paintings or keep staring at their smartphones, with their feet immersed in water for some time. (Fig. 7d)

A massive tree stump, several branches and a carpet of leaves a hal 1 - but the solitary visitor, unaware of the intrusion of nature, remains engrossed in the contemplation of the work of art.

Nature returns to the realms of culture, even to an art temple par excellence. The paintings that hang there have often fed on nature, and they have shaped our perception of it. But they have also paved the way for some non-perception and oversight, and fostered many a cultural blindness. Now, undomesticated nature returns and, unabashed, enters the sacred halls of art. And people, these cultural beings and art lovers, do not even notice. With all our respect for nature and all our reflection on it, we have become blind to elementary natural phenomena.

This leads us back to the Anthropocene. For this epoch implies not only - as its cause - the human disregard, exploitation and destruction of nature. It could also include - as a consequence and final development - the fall of human culture that continues to ignore the signals sent out by nature. And then, in the end, nature which in no way cares about humans might come to dominate and determine the further fate of this planet.

\section{Cosmo-Eggs - 1ucky exit?}

There are also (gently) more optimistic perspectives. Maybe we'll make tracks again. A look back at history could raise hopes.

The last work I am presenting is Cosmo-Eggs, which can be seen in the Japanese Pavilion at the $58^{\text {th }}$ Venice Biennial in 2019. It is the joint work of an artist Motoyuki Shitamichi, an anthropologist Toshiaki Ishikura, a composer Taro Yasuno, and an architect Fuminori Nousaku. (Fig. 8a, 8b, 8c, 8d) 
The starting point of this work are so-called tsunami boulders, which can be found on some Japanese islands (and also elsewhere in Asia). They derive from the seabed and have been washed ashore by tsunamis (which have occurred in this region for thousands of years). These boulders are attractions, some are revered, and they provide nesting places for birds.

Shitamichi, the artist, was fascinated by these boulders and wondered what they could tell us about our history and future. He contacted Ishikura, the anthropologist, who set out to study ancient myths and tales relating to tsunami boulders, and finally he made an impressive story from these materials.

Here is its first part which describes the initial situation:

A long time ago, sun and moon descended to earth and laid a single egg. A snake came and swallowed the egg, and so sun and moon visited earth once more to leave behind three eggs that they hid: one inside earth, one inside stone, and one inside bamboo. The eggs soon hatched, and born were the ancestors of three islands. Once grown up, they each built a small boat and travelled to different islands: one in the East, one in the West, and one in the North. The tribes of these islands visited each other by boat, and despite occasional fights, they overcame pestilence and poor harvests to live in peace for a long time. Each island passed down its own language, its own music, its own traditions, its own festivals. They each possessed the power to speak with the animals: the earth tribe spoke with the worms and the insects, the stone tribe with the snakes, and the bamboo tribe with the birds. ${ }^{15}$
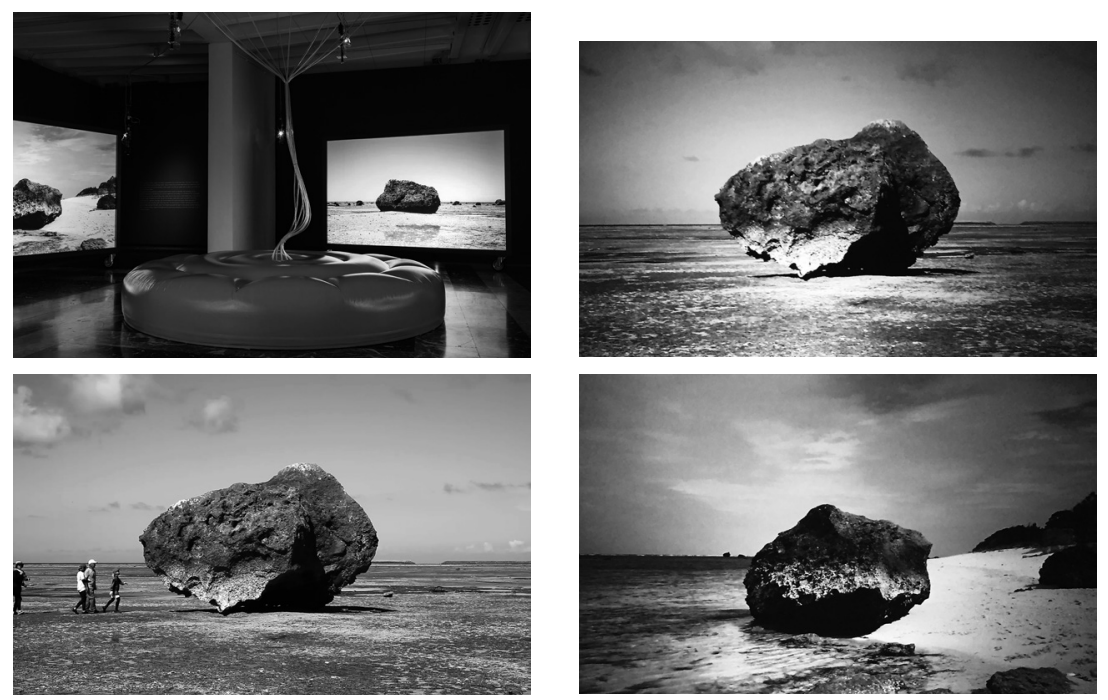

Fig. 8a-d. Shitamichi / Ishikura / Yasuno / Nousaku, Cosmo-Eggs, 2018, The Japan Pavilion at the 58 Venice Art Biennale 2019 
This is followed by three similar stories which describe the next period, with each story being about one of the three islands. Here's the one from the stone island:

A youth slept and in his dreams saw a flock of white birds drop giant boulders down from the skies and into the fields. On the seashore the next morning, he caught a fish that knew the language of man. It begged him not to be eaten, and so the youth made return it to the sea. But the father who had watched the youth took the rare fish from him and, as a lesson, decided to eat it. The fish cried out for help, and from the sea arose a tremendous tsunami. Like a swan spreading its wings the tsunami swept over the island, and the enormous wave swallowed all living creatures. It left behind boulders covered in corals, and the animals it had drowned became hermit crabs. The youth, however, had fled with his sister to the island's highest mountain and, clinging to a rock, the two barely survived. They were able to overcome starvation, and brother and sister coupled and gave birth to new offspring. ${ }^{16}$

Although the situation was paradisiacal to start off with, there were fights and poor harvests, but the people came to terms with the difficulties and lived respecting each other and nature. But then a rupture and a disaster happened on each one of the islands. Human society was under urgent threat. And this catastrophe was (in all the three cases) not caused by nature but - as in the Anthropocene - by humans. Finally, however, people managed once again to escape the catastrophe and to find a new balance with nature. Coexistence between humans and nature and peace among humans - is the key concept of work. I would have awarded it the main prize of the Biennale. It gives us some hope.

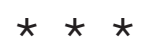

I wanted to give a few examples of how artists imagine an end or overcoming the Anthropocene. My work is not about elements of a theory. Frankly, none of us know what the future will bring. We're at best, but actually ignorant. The artists show us possibilities, they offer experimental spaces for imagination and reflection. Art is in league with the sense of possibility. What reality will be like in the future cannot be shaped by art, but by us as political and acting citizens. Maybe we'll pass the test. If we fail, it was certainly not be the fault of art. 
Denis Diderot, "Encyclopedia [1755]," in The Encyclopedia of Diderot \& d'Alembert Collaborative Translation Project, transl. Philip Stewart (Ann Arbor: Michigan Publishing, University of Michigan Library, 2002), vol. 5, 641.

Denis Diderot, “D‘Alembert‘s Dream” [written in 1769, first published in 1830], in: ibidem, Geschichten und Gespräche (Leipzig: Dieterich 1953), 436-501, here p. 446 [transl. W.W.].

Ibid., 454.

Ibid., 446 .

Ibid., 452 .

Cf. in more detail on the modern form of thought and its transgression my Homo mundanus Jenseits der anthropischen Denkform der Moderne (Weilerswist: Velbrück Wissenschaft 2012, $2^{\text {nd }}$ edition 2015) as well as Mensch und Welt - Eine evolutionäre Perspektive der Philosophie (Munich: Beck 2012).

The term "Anthropocene" is certainly not unproblematic. Nevertheless, I use it here, as it is in circulation. Cf. to a more detailed discussion essay: Wolfgang Welsch, "Wohin treibt das Anthropozän?," in Wer sind wir? (Vienna: new academic press 2019), 144-163.

Gottfried Benn, "Roman des Phänotyp," in Gesammelte Werke in vier Bänden, ed. Dieter Wellershoff, vol. 2 (Wiesbaden: Limes 1958), 161.

My aesthetic critique could be complemented by Timothy Morton's conceptual critique, according to which ecological thinking is still based on the categorical distinction between nature on the one hand and civilisation on the other, which, however, is typical of modern thinking and therefore co-responsible for the problems we face (cf. Timothy Morton, Ecology without Nature, 2007, and The Ecological Thought, 2010). Already in the 1970s artist Robert Smithson stated: 'The ecology thing has a kind of religious, ethical undertone to it. It's like the official religion now, but I think a lot of it is based on a kind of late nineteenth-century, puritanical view of nature. In the puritan ethic, there's a tendency to put man outside nature, so that whatever he does is fundamentally unnatural and there's no need to refer to nature anymore.' (Robert Smithson, quoted after: Calvin Tomkins, The Scene: Reports on Post-Modern Art, New York 1976, 144).

Cf. the ideas of extropianism (Max More) and postbiological evolution (Steven J. Dick).

"Jardin gobe-avions" means "airplane snapping garden".

https://www.rimini-protokoll.de/website/de/project/win-win.

It depends on growing in symbiosis with the roots of various tree species (preferably the Japanese red pine).

Cf. author, "Fluchtpunkt Natur - Zur ästhetischen Situation der Gegenwart," in Ästhetische Welterfahrung - Zeitgenössische Kunst zwischen Natur und Kultur (Munich: Fink 2016), 47. 
Benn, Gottfried. "Roman des Phänotyp.” In Gesammelte Werke in vier Bänden, edited by Dieter Wellershoff, vol. 2, 152-204. Wiesbaden: Limes, 1958.

Cosmo-Eggs. Exhibition catalogue. Tokyo: Case Publishing, 2019.

Dick, Steven J. The Biological Universe. The Twentieth-Century Extraterrestrial Life Debate and the Limits of Science. Cambridge, Mass.: Cambridge University Press 1996.

Diderot, Denis. “Encyclopedia[1755].” In The Encyclopedia of Diderot \& d'Alembert Collaborative Translation Project, vol. 5, translated by Philip Stewart, 635-648. Ann Arbor: Michigan Publishing, University of Michigan Library, 2002.

Diderot, Denis. “D'Alembert's Dream” [written in 1769, first published in 1830], translated by Ian Johnston. Vancouver Island University, 2014.

http://johnstoniatexts.x10host.com/diderot/diderottofc.html.

Lovelock, James. Gaia: A New Look at Life on Earth. Oxford: Oxford University Press 1979.

Moore, Jason W. (editor). Anthropocene or Capitalocene? Nature, History, and the Crisis of Capitalism. Oakland, CA: PM Press 2016.

More, Max. The Philosophy of Transhumanism. Oxford: John Wiley \& Sons, 2013.

Morton, Timothy. Ecology without Nature: Rethinking Environmental Aesthetics. Cambridge, Mass.: Harvard University Press 2007.

Morton, Timothy. The Ecological Thought. Cambridge, Mass.: Harvard University Press, 2010.

Tomkins, Calvin. The Scene: Reports on Post-Modern Art. New York, 1976.

Rimini Protokoll. https:/www.rimini-protokoll.de/website/de/project/win-win; accessed on 11/19/2019.

Welsch, Wolfgang. Mensch und Welt - Eine evolutionäre Perspektive der Philosophie. Munich: Beck 2012.

Welsch, Wolfgang. Homo mundanus - Jenseits der anthropischen Denkform der Moderne. Weilerswist: Velbrück Wissenschaft 2012, 2nd edition 2015.

Welsch, Wolfgang. "Fluchtpunkt Natur - Zur ästhetischen Situation der Gegenwart," in: ibidem, Ästhetische Welterfahrung - Zeitgenössische Kunst zwischen Natur und Kultur. Munich: Fink, 2016, 35-48.

Welsch, Wolfgang. "Wohin treibt das Anthropozän?." In Wer sind wir?, 144-163. Vienna: new academic press, 2019. 


\section{UMETNOST KOJA SE BAVI ANTROPOCENOM}

\section{Wolfgang Welsch}

Trenutna dijagnoza da doba u kom živimo treba da se zamisli kao antropocen ima dve implikacije: a) Ljudska aktivnost menja površnu i duboku strukturu naše planete do ranije nepoznatog stepena, b) Predvidljive katastrofalne posledice našeg uticaja na život na ovoj planeti zahtevaju fundamentalne promene našeg tehnološko-potrošačkog stava. - Kako umetnost može da pomogne u rešavanju ove situacije?

Jedna (relativno površna) opcija je ekološka umetnost. Ali, uprkos svim dobrim namerama, ona često samo doprinosi raširenim sedativnim postupcima koji nas sprečavaju u preduzimanju neophodnih mera. Drugačija opcija sastoji se od istraživanja moguće budućnosti planete koja više ne računa i ne oslanja se na ljude (koja bi, zbog njihovih aktivnosti, u svakom slučaju mogla da nestane za nekoliko decenija). Tada bi priroda mogla ponovo da krene svojim putem. Kako umetnost može da zamisli stanje naše planete koja se vise me zasniva na uticaju ljudi? Ovaj rad pokušava da razjasni neke primere iz umetnosti. Na kraju, međutim, prikaz mogućeg nestajanja ljudi takođe podstiče napore da se to izbegne.

KLJUČNE REČI: ANTROPOCEN; SAVREMENA UMETNOST; NOVE ŽIVOTNE FORME; MUZEJI KOJI NAPADAJU PRIRODU; ZEMLJA BEZ LJUDI; EKOLOŠKA UMETNOST; BUDUĆNOST; CUNAMI PREPREKE 